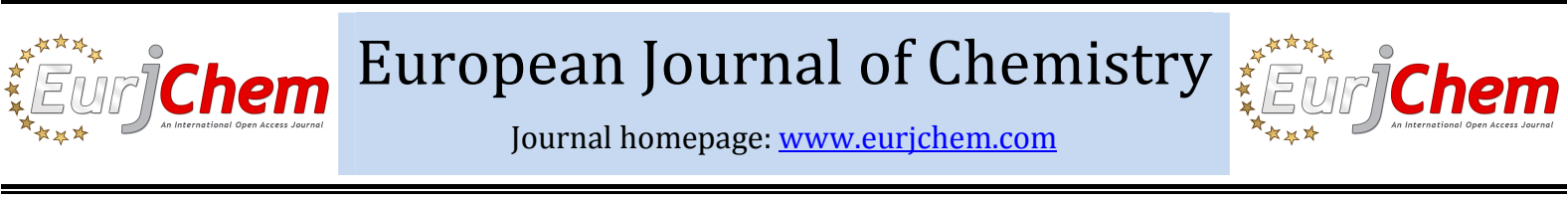

\section{Synthesis of novel pyrimidine and fused pyrimidine derivatives}

\author{
Mahmoud Refaee Mahmoud, Ahmed Kamel El-Ziaty, \\ Mahmoud Fawzy Ismail* and Sayed Ahmed Shiba
}

Chemistry Department, Faculty of Science, Ain Shams University, Abbassia, Cairo, 11566, Egypt

*Corresponding author at: Chemistry Department, Faculty of Science, Ain Shams University, Abbassia, Cairo, 11566, Egypt. Tel.: +0224831836; fax: +202.24831836. E-mail address: fawzy2010@sci.asu.edu.eg (M.F. Ismail).

\section{ARTICLE INFORMATION}

Received: 15 June 2010

Received in revised form: 26 October 2010

Accepted: 08 November 2010

Online: 30 September 2011

\section{KEYWORDS}

s-Benzylthiuronium chloride

Activated nitriles

Pyrimidines

Triazolopyrimidine derivatives

Antiviral activity

Cytotoxicity

\section{Introduction}

The recent wide applications of pyrimidine derivatives as anti-tumor [1], anti-HIV-1 [2], analgesic [3], anti-depressive [4], anti-convulsant [5], anti-microbial [6], herbicides [7,8], antiinflammatory and antioxidant [3,9], beside their uses as a precursors in the synthesis of fused ring compounds like, triazolopyrimidines as antibacterial agents [10], fungicidal [11], and anti-tumor agents [12], imidazopyrimidines as antimycobacterial [13] and pyridopyrimidines as antibacterial agents [14] make them worthy to be synthesized and evaluated as drugs. We report here synthesis of pyrimidine and fused pyrimidines by developed, simple, convenient and efficient procedure. Also, this modified method is fast, cheap and unequivocal preparation with improved yields.

\section{Experimental}

\subsection{Instrumentation}

Melting points are uncorrected and were measured by an electric melting point apparatus (G-K). The IR spectra were recorded on a Pye-Unicam SP1200 spectrophotometer using $\mathrm{KBr}$ Wafer technique. The ${ }^{1} \mathrm{H}$ NMR spectra were determined on a Varian GEMINI $300 \mathrm{MHz}$ NMR spectrophotometer using $\mathrm{CDCl}_{3}$ or DMSO- $d_{6}$ as solvent and TMS as an internal standard. All chemical shifts are in ppm downfield from TMS. The elemental analysis was carried out in faculty of Science, Ain Shams University. MS were recorded on Shimadzu GC-MS QP1000EX instrument in micro analytical lab, Cairo University. The monitoring of the progress of all reactions and homogeneity of the synthesized compound was carried out by TLC.

\subsection{Synthesis}

\subsubsection{4-amino-2-(benzylthio)-6-(4-methoxyphenyl) pyrimidine-5-carbonitrile (1)}

To a solution of s-benzylthiuronium chloride $(2.02 \mathrm{~g}, 0.01$ mol) in water $(10 \mathrm{~mL})$, sodium hydroxide $(1 \mathrm{~N}, 10 \mathrm{~mL})$ was added dropwise with shaking, the pale green precipitate so formed, was dissolved in warmed ethanol $(10 \mathrm{~mL})$, then a solution of 2-(4-methoxybenzylidene)malononitrile (1.84 g, $0.01 \mathrm{~mol})$ in ethanol $(20 \mathrm{~mL})$ was added and the whole mixture was heated under reflux for $5 \mathrm{~h}$. The solid formed after cooling was collected by filtration and recrystallized from toluene to give 1 as buff crystals (Scheme 1). Yield: 82\%. M.p.: $171-173{ }^{\circ} \mathrm{C}$. FT-IR $\left(\mathrm{KBr}, \mathrm{cm}^{-1}\right): 3461,3298 \mathrm{v}\left(\mathrm{NH}_{2}\right), 2204 \mathrm{v}(\mathrm{C} \equiv \mathrm{N}), 1626$ $\mathrm{v}(\mathrm{C}=\mathrm{N}) .{ }^{1 \mathrm{H}} \mathrm{NMR}\left(300 \mathrm{MHz}, \mathrm{CDCl}_{3}\right): 8.03(\mathrm{~d}, J=8.4 \mathrm{~Hz}, 2 \mathrm{H}, \mathrm{Ar}-\mathrm{H})$, 7.40-7.27 (m, 5H, Ar- $H$ ), 7.00 (d, J=8.7 Hz, 2H, Ar- $H$ ), 5.67 (s, $2 \mathrm{H}$, $\mathrm{CH}_{2}$ ), 4.45 (br.s, $2 \mathrm{H}, \mathrm{NH}_{2}$, exchangeable with $\mathrm{D}_{2} \mathrm{O}$ ), 3.89 (s, $3 \mathrm{H}$, $\mathrm{OCH}_{3}$ ). MS (EI, m/z): $348\left(\mathrm{M}^{+}\right)$. Anal. Calcd. for $\mathrm{C}_{19} \mathrm{H}_{16} \mathrm{~N}_{4} \mathrm{OS}$ : C, 65.50; H, 4.63; N, 16.08; S, 9.20. Found: C, 65.52; H, 4.59; N, $16.02 ; \mathrm{S}, 9.12 \%$.

\subsubsection{4-amino-2-hydrazinyl-6-(4-methoxyphenyl) pyrimidine-5-carbonitrile (2)}

A mixture of 1 (3.48 g, $0.01 \mathrm{~mol}$ ) and hydrazine hydrate $80 \%(0.015 \mathrm{~mol})$ in ethanol $(50 \mathrm{~mL})$ was heated under reflux for $3 \mathrm{~h}$. The colourless solid separated on hot was collected by filtration and then recrystallized from dioxane to give $\mathbf{2}$ as colourless crystals (Scheme 2). Yield 35\%. M.p.: 300-302 ${ }^{\circ} \mathrm{C}$. FTIR $\left(\mathrm{KBr}, \mathrm{cm}^{-1}\right): 3454,3302 \mathrm{v}\left(\mathrm{NH}_{2}, \mathrm{NH}\right), 2194 \mathrm{v}(\mathrm{C} \equiv \mathrm{N}), 1634$ $\mathrm{v}(\mathrm{C}=\mathrm{N})$. MS (EI, m/z): $256\left(\mathrm{M}^{+}\right)$. Anal. Calcd. for $\mathrm{C}_{12} \mathrm{H}_{12} \mathrm{~N}_{6} \mathrm{O}: \mathrm{C}$, $56.24 ; \mathrm{H}, 4.72$; N, 32.79. Found: C, 56.13; H, 4.62; N, 32.81\%. 


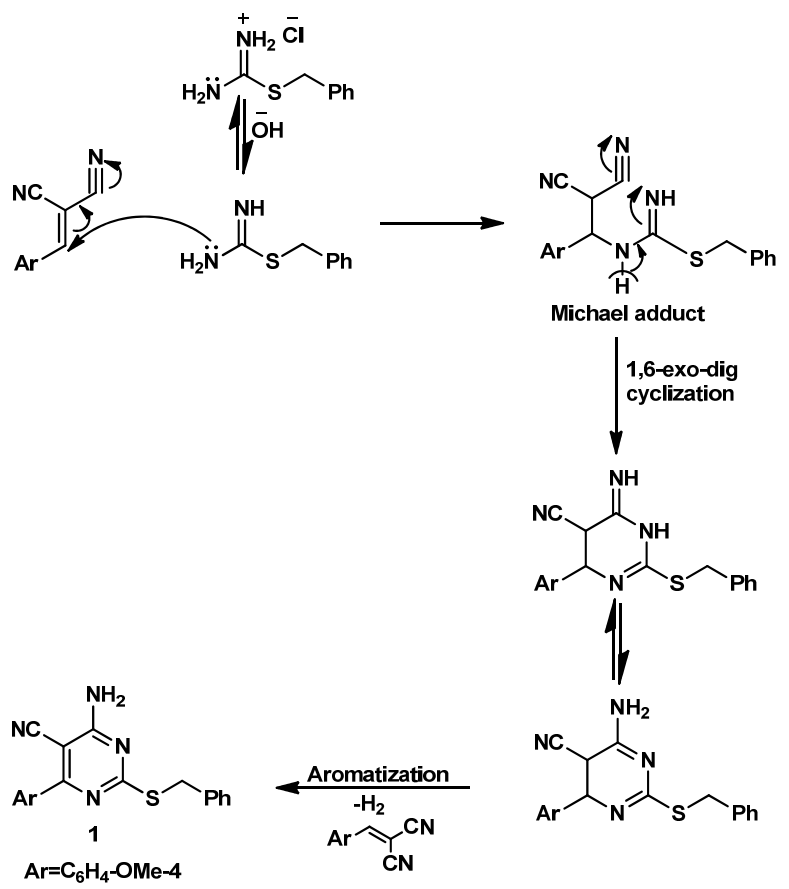

Scheme 1

2.2.3. 4-amino-2-(3,5-dimethyl-1H-pyrazol-1-yl)-6-(4methoxyphenyl)pyrimidine-5-carbonitrile (3)

A mixture of compound $2(1.0 \mathrm{~g}, 3.9 \mathrm{mmol})$ and pentane2,4-dione $(0.4 \mathrm{ml}, 3.9 \mathrm{mmol})$ in ethanol $(25 \mathrm{~mL})$ was heated under reflux for $6 \mathrm{~h}$. The solid deposited while hot was collected by filtration and crystallized from dioxane to give $\mathbf{3}$ as colourless crystals (Scheme 2). Yield 86\%. M.p.: 280-282 ${ }^{\circ} \mathrm{C}$. FTIR (KBr, cm-1): 3477, 3273 v( $\left.\mathrm{NH}_{2}\right), 2206 \mathrm{v}(\mathrm{C} \equiv \mathrm{N}), 1648 \mathrm{v}(\mathrm{C}=\mathrm{N})$. ${ }^{1} \mathrm{H}$ NMR (300 MHz, DMSO- $d_{6}$ ): 7.96 (d, $J=9 \mathrm{~Hz}, 2 \mathrm{H}, \mathrm{Ar}-H$ ), 7.13 (d, J=8.8 Hz, 2H, Ar- $H$ ), 6.1 (s, $1 \mathrm{H},=\mathrm{C}_{4}-H$ ), 4.2 (br.s, $2 \mathrm{H}, \mathrm{NH}_{2}$, exchangeable with $\left.\mathrm{D}_{2} \mathrm{O}\right), 3.86\left(\mathrm{~s}, 3 \mathrm{H}, \mathrm{OCH}_{3}\right), 3.3\left(\mathrm{~s}, 3 \mathrm{H}, \mathrm{C}_{3}-\mathrm{CH}_{3}\right)$, 2.1 (s, 3H, $\left.\mathrm{C}_{5}-\mathrm{CH}_{3}\right)$. MS (EI, m/z): $320\left(\mathrm{M}^{+}\right)$. Anal. Calcd. for $\mathrm{C}_{17} \mathrm{H}_{16} \mathrm{~N}_{6} \mathrm{O}: \mathrm{C}, 63.74 ; \mathrm{H}, 5.03 ; \mathrm{N}, 26.23$. Found: C, 63.75; H, 4.47; $\mathrm{N}, 26.25 \%$.

\subsubsection{N-(5-Cyano-2-(2,2-diacetylhydrazinyl)-6-(4-methoxy phenyl)pyrimidin-4-yl) acetamide (4)}

A solution of $2(1.0 \mathrm{~g}, 3.9 \mathrm{mmol})$ in freshly distilled acetic anhydride $(10 \mathrm{~mL})$ was heated under reflux for $6 \mathrm{~h}$. After cooling, the reaction mixture was poured on ice cold water. The crude deposited was collected and crystallized from ethanol to give $\mathbf{4}$ as colourless crystals (Scheme 2). Yield 76\%. M.p.: 182$184{ }^{\circ} \mathrm{C}$. FT-IR $\left(\mathrm{KBr}, \mathrm{cm}^{-1}\right): 3368 \mathrm{v}(\mathrm{NH}), 2216 \mathrm{v}(\mathrm{C} \equiv \mathrm{N}), 1716$ $\mathrm{v}(\mathrm{C}=0) . \quad{ }^{1} \mathrm{H}$ NMR $\left(300 \mathrm{MHz}, \mathrm{CDCl}_{3}\right): 8.17 \quad(\mathrm{~s}, 1 \mathrm{H}, \mathrm{NH}$, exchangeable with $\left.\mathrm{D}_{2} \mathrm{O}\right), 8.03(\mathrm{~d}, J=8.8 \mathrm{~Hz}, 2 \mathrm{H}, \mathrm{Ar}-H), 7.27(\mathrm{~s}$, $1 \mathrm{H}, \mathrm{N} H$, exchangeable with $\left.\mathrm{D}_{2} \mathrm{O}\right), 7.03(\mathrm{~d}, J=8.8 \mathrm{~Hz}, 2 \mathrm{H}, \mathrm{Ar}-\mathrm{H})$, $3.91\left(\mathrm{~s}, 3 \mathrm{H}, \mathrm{OCH}_{3}\right), 2.85\left(\mathrm{~s}, 3 \mathrm{H}, \mathrm{CH}_{3}\right), 2.44\left(\mathrm{~s}, 6 \mathrm{H}, 2 \mathrm{COCH}_{3}\right)$. MS (EI, m/z(\%)): $382\left(\mathrm{M}^{+}\right.$). Anal. Calcd. for $\mathrm{C}_{18} \mathrm{H}_{18} \mathrm{~N}_{6} \mathrm{O}_{4}$ : C, 56.54; $\mathrm{H}$, 4.74; N, 21.98. Found: C, 56.37; H, 4.62; N, 21.81\%.

\subsection{5. $N$-(4-amino-5-cyano-6-(4-methoxyphenyl)pyrimidin- 2-yl)furan-2-carbohydrazide (5)}

A mixture of $2(1.0 \mathrm{~g}, 3.9 \mathrm{mmol})$ and furoyl chloride $(0.51$ $\mathrm{mL}, 3.9 \mathrm{mmol})$ in pyridine $(20 \mathrm{~mL})$ was heated under reflux for $3 \mathrm{~h}$. After cooling the reaction mixture acidified on ice cold acetic acid. The deposited was filtered off, washed several times with cold water and recrystallized from toluene to give $\mathbf{5}$ as pale yellow crystals (Scheme 2). Yield 52\%. M.p.: $110-112{ }^{\circ} \mathrm{C}$. FT-IR (KBr, cm $\left.{ }^{-1}\right): 3455,3318,3219$ v(NH2, NH), $2206 \mathrm{v}(\mathrm{C} \equiv \mathrm{N})$, $1680 \mathrm{v}(\mathrm{C}=0)$ (hydrazide). MS (EI, m/z): $350\left(\mathrm{M}^{+}\right)$. Anal. Calcd. for $\mathrm{C}_{17} \mathrm{H}_{14} \mathrm{~N}_{6} \mathrm{O}_{3}$ : C, 58.28; $\mathrm{H}, 4.03 ; \mathrm{N}, 23.99$. Found: $\mathrm{C}, 58.35 ; \mathrm{H}$ $4.12 ; \mathrm{N}, 24.14 \%$.

\subsubsection{4-amino-2-(1,3-dioxoisoindolin-2-ylamino)-6-(4- methoxyphenyl)pyrimidine-5-carbonitrile (6)}

A mixture of $2(1.0 \mathrm{~g}, 3.9 \mathrm{mmol})$ and phthalic anhydride $(0.58 \mathrm{~g}, 3.9 \mathrm{mmol})$ in glacial acetic acid was heated under reflux for one hour. The white solid deposited while hot was collected by filtration and then recrystallized from dioxane to give 6 as colourless crystals (Scheme 2). Yield 75\%. M.p.: over $300{ }^{\circ} \mathrm{C}$. FT-IR (KBr, cm-1): 3414, 3374, 3333, $3168 v\left(\mathrm{NH}_{2}, \mathrm{NH}\right), 2205$ $\mathrm{v}(\mathrm{C} \equiv \mathrm{N}), 1791,1731 \mathrm{v}(\mathrm{C}=0)$ (coupling bands). MS (EI, m/z): $386\left(\mathrm{M}^{+}\right)$. Anal. Calcd. for $\mathrm{C}_{20} \mathrm{H}_{14} \mathrm{~N}_{6} \mathrm{O}_{3}$ : C, 62.17; $\mathrm{H}, 3.65 ; \mathrm{N}, 21.75$. Found: C, 62.18; H, 3.63; N, 21.76\%.

\subsubsection{Ethyl 2-(4-amino-5-cyano-6-(4-methoxyphenyl) pyrimidin-2-yl)hydrazinecarboxylate (7)}

A mixture of $2(1.0 \mathrm{~g}, 3.9 \mathrm{mmol})$ and ethyl chloroformate $(0.4 \mathrm{~mL}, 3.9 \mathrm{mmol})$ in pyridine $(20 \mathrm{~mL})$ was heated under reflux for $6 \mathrm{~h}$. The reaction mixture was concentrated, and acidified with cold dilute acetic acid. The solid separated out was filtered off, washed several times with cold water and recrystallized from ethanol to give $\mathbf{7}$ as colourless crystals (Scheme 2). Yield 84\%. M.p.: 201-203 ${ }^{\circ} \mathrm{C}$. FT-IR $\left(\mathrm{KBr}, \mathrm{cm}^{-1}\right)$ : 3468, 3345, 3312, $3173 \mathrm{v}\left(\mathrm{NH}_{2}\right), 2202 \mathrm{v}(\mathrm{C} \equiv \mathrm{N}), 1706 \mathrm{v}(\mathrm{C}=0)$ (ester). ${ }^{1} \mathrm{H}$ NMR $\left(300 \mathrm{MHz}\right.$, DMSO- $\left.d_{6}\right): 9.2-9.1(\mathrm{~d}, 2 \mathrm{H}, 2 \mathrm{NH}$ exchangeable with $\left.\mathrm{D}_{2} \mathrm{O}\right), 7.82(\mathrm{~d}, J=8.6 \mathrm{~Hz}, 2 \mathrm{H}, \mathrm{Ar}-\mathrm{H}), 7.08(\mathrm{~d}$, $J=8.6 \mathrm{~Hz}, 2 \mathrm{H}, \mathrm{Ar}-\mathrm{H}$ ), $4.1\left(\mathrm{q}, 2 \mathrm{H}, \mathrm{COOCH}_{2} \mathrm{CH}_{3}\right), 4.0$ (br.s, $2 \mathrm{H}, \mathrm{NH}_{2}$, exchangeable with $\left.\mathrm{D}_{2} \mathrm{O}\right), 3.8\left(\mathrm{~s}, 3 \mathrm{H}, \mathrm{OCH}_{3}\right), 1.2-1.05(\mathrm{t}, 3 \mathrm{H}$, $\left.\mathrm{COOCH}_{2} \mathrm{CH}_{3}\right)$. MS (EI, m/z): $328\left(\mathrm{M}^{+}\right)$. Anal. Calcd. for $\mathrm{C}_{15} \mathrm{H}_{16} \mathrm{~N}_{6} \mathrm{O}_{3}: \mathrm{C}, 54.87 ; \mathrm{H}, 4.91 ; \mathrm{N}, 25.60$. Found: $\mathrm{C}, 54.82 ; \mathrm{H}, 4.86$; N, $25.61 \%$. 


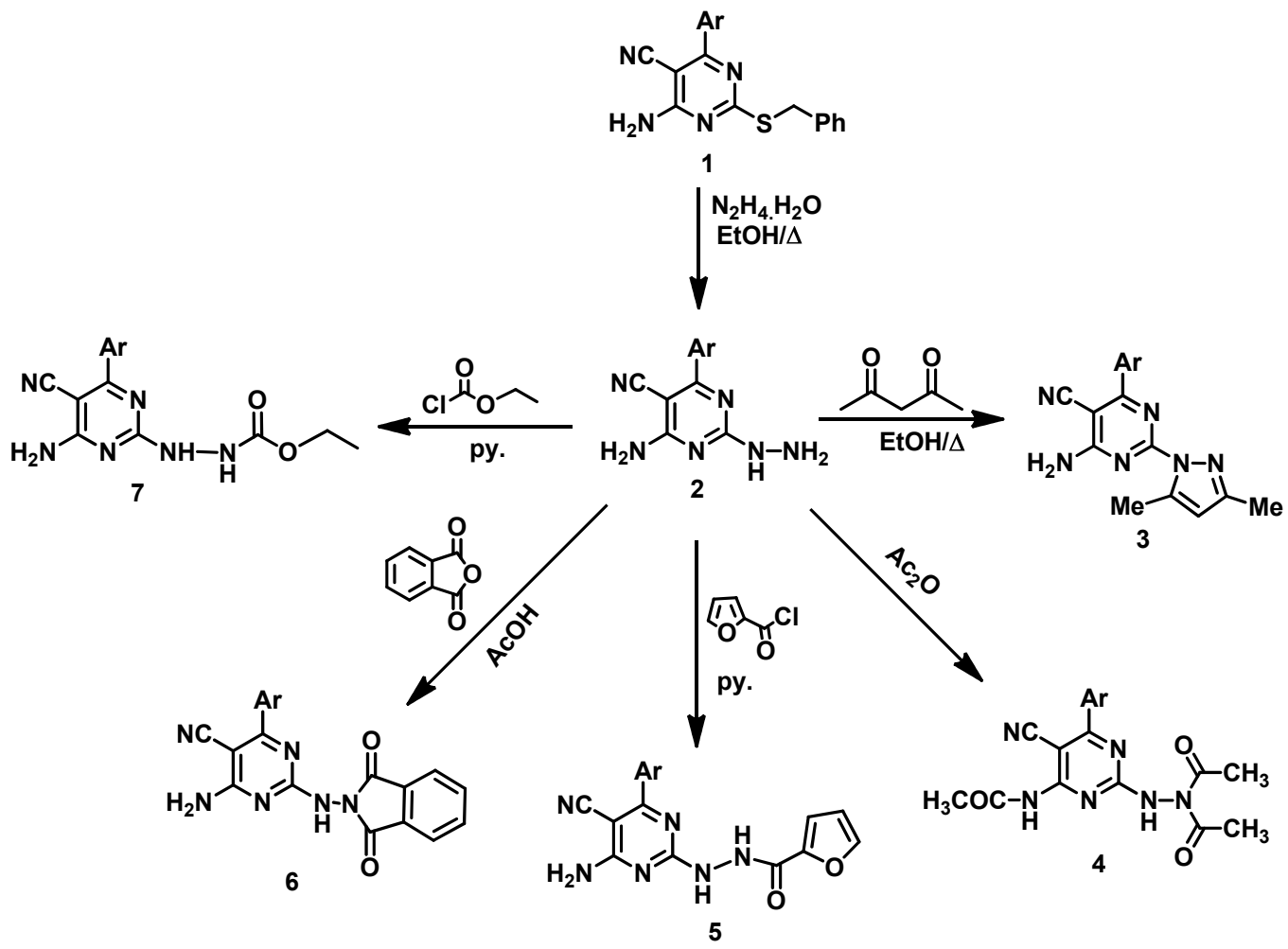

Scheme 2

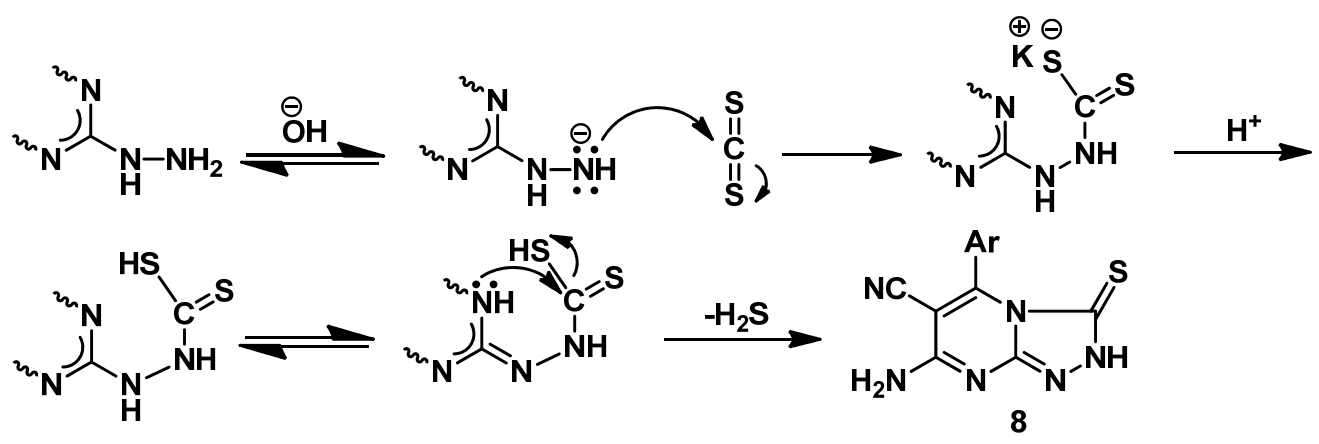

Scheme 3

2.2.8. 7-amino-5-(4-methoxyphenyl)-3-thioxo-2,3-dihydro[1,2,4]triazolo[4,3-a]pyrimidine-6-carbonitrile (8)

A mixture of $2(1.0 \mathrm{~g}, 3.9 \mathrm{mmol})$ and carbon disulphide (5 $\mathrm{mL}$ ) in ethanolic $\mathrm{KOH} 10 \%$ (1.0 g KOH dissolve in $1.0 \mathrm{~mL}$ water and $9 \mathrm{~mL}$ ethanol) was heated under reflux on water bath for 16h. After cooling the reaction mixture was acidified with cold dilute acetic acid. The canary yellow solid that separated out was filtered off, washed several times with cold water and recrystallized from ethanol to give $\mathbf{8}$ as canary yellow crystals (Scheme 3). Yield 48\%. M.p.: $278-280{ }^{\circ} \mathrm{C}$. FT-IR $\left(\mathrm{KBr}, \mathrm{cm}^{-1}\right)$ : $3292,3213,3198 \cup\left(\mathrm{NH}_{2}, \mathrm{NH}\right), 2210 v(\mathrm{C} \equiv \mathrm{N}), 1632 \cup(\mathrm{C}=\mathrm{N}), 1259$ $\mathrm{v}(\mathrm{C}=\mathrm{S})$. MS (EI, m/z): $298\left(\mathrm{M}^{+}\right)$. Anal. Calcd. for $\mathrm{C}_{13} \mathrm{H}_{10} \mathrm{~N}_{6} \mathrm{OS}: \mathrm{C}$, 52.34; H, 3.38; N, 28.17; S, 10.75. Found: C, 52.35; H, 3.36; N, 28.19; S, 10.74\%.
2.2.9. 7-amino-3-(3,4-dimethoxyphenyl)-5-(4-methoxy phenyl)-[1,2,4]triazolo[4,3-a] pyramidine-6-carbonitrile (9)

A mixture of 2 (1.0 g, $3.9 \mathrm{mmol})$ and 2-(3,4dimethoxybenzylidene) malononitrile $(0.83 \mathrm{~g}, 3.9 \mathrm{mmol})$ in ethanol $(25 \mathrm{~mL})$ and drops of glacial acetic acid was heated under reflux for $6 \mathrm{~h}$. After evaporation of the solvent in vacuo, the solid obtained was collected by filtration and recrystallized from toluene to give $\mathbf{9}$ as pale yellow crystals (Scheme 4). Yield 74\%. M.p.: $217-220{ }^{\circ} \mathrm{C}$. FT-IR $\left(\mathrm{KBr}, \mathrm{cm}^{-1}\right): 3460,3292$ v( $\left.\mathrm{NH}_{2}\right)$, $2200 v(\mathrm{C} \equiv \mathrm{N}), 1643 \mathrm{v}(\mathrm{C}=\mathrm{N}) .{ }^{1} \mathrm{H}$ NMR (300 MHz, DMSO- $\left.d_{6}\right): 8.12$ (s, 1H, Ar- $H$ ), 7.86 (d, J=8.4 Hz, 2H, Ar-H), 7.30-7.10 (br.s, 2H, $\mathrm{N} H_{2}$, exchangeable with $\left.\mathrm{D}_{2} \mathrm{O}\right), 7.18-6.98(\mathrm{~m}, 4 \mathrm{H}, \mathrm{Ar}-\mathrm{H}), 3.83(\mathrm{~s}$, $\left.6 \mathrm{H}, 2 \mathrm{OCH} \mathrm{C}_{3}\right), 3.79\left(\mathrm{~s}, 3 \mathrm{H}, \mathrm{OCH}_{3}\right)$. MS (EI, m/z): $403(\mathrm{M}+1)$. Anal. Calcd. for $\mathrm{C}_{21} \mathrm{H}_{18} \mathrm{~N}_{6} \mathrm{O}_{3}$ : C, 62.68; $\mathrm{H}, 4.51 ; \mathrm{N}, 20.88$. Found: C, 62.59; H, 4.48; N, 20.76\%. 


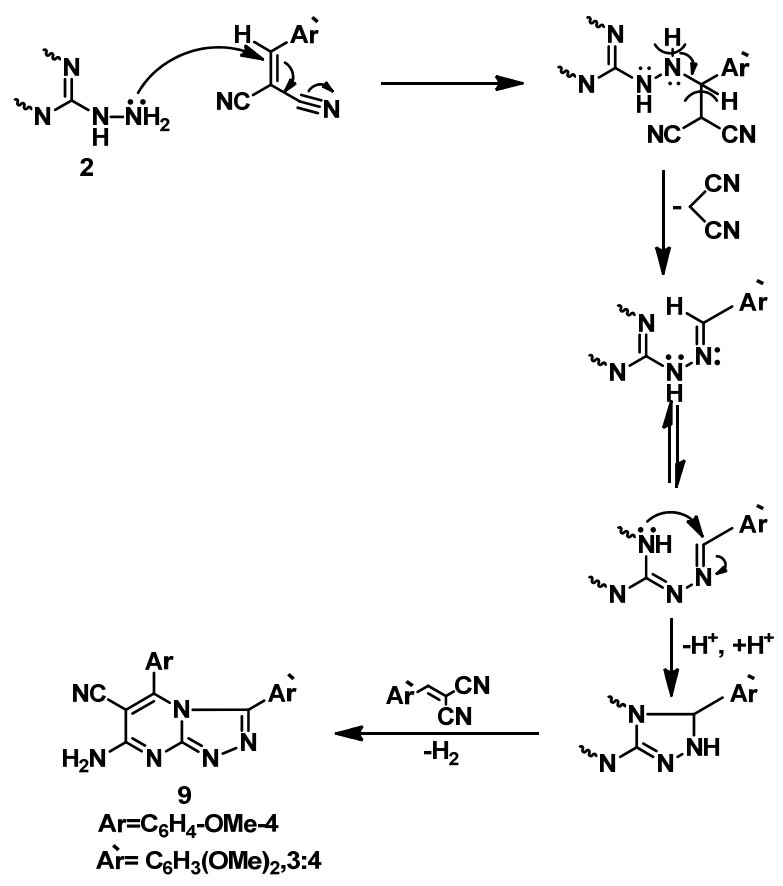

Scheme 4

2.2.10. (E)-2-(2-(4-nitrobenzylidene)hydrazinyl)-4-amino-6(4-methoxyphenyl)pyrimidine-5-carbonitrile (10)

A mixture of $2(1.0 \mathrm{~g}, 3.9 \mathrm{mmol})$ and p-nitrobenzaldehyde $(0.59 \mathrm{~g}, 3.9 \mathrm{mmol})$ in ethanol $(25 \mathrm{~mL})$ was stirred under reflux for $10 \mathrm{~min}$. The solid separated was collected by filtration and then recrystallized from ethanol/dioxane mixture to give $\mathbf{1 0}$ as yellow crystals (Scheme 5). Yield $98 \%$. M.p.: over $300{ }^{\circ} \mathrm{C}$. FT-IR $\left(\mathrm{KBr}, \mathrm{cm}^{-1}\right): 3478,3294,3149 \cup\left(\mathrm{NH}_{2}\right), 2201 \mathrm{v}(\mathrm{C} \equiv \mathrm{N}), 1647$ $\mathrm{v}(\mathrm{C}=\mathrm{N}) .{ }^{1} \mathrm{H}$ NMR $\left(300 \mathrm{MHz}\right.$, DMSO-d $\left.d_{6}\right): 11.7(\mathrm{~s}, 1 \mathrm{H}, \mathrm{NH}$, exchangeable with $\left.\mathrm{D}_{2} \mathrm{O}\right), 8.29(\mathrm{~m}, 3 \mathrm{H},(2 \mathrm{H}, \mathrm{Ar}-\mathrm{H})$ and $\mathrm{N}=\mathrm{CH})$, $7.92(\mathrm{~d}, J=9 \mathrm{~Hz}, 2 \mathrm{H}, \mathrm{Ar}-H), 7.84(\mathrm{~d}, J=9 \mathrm{~Hz}, 2 \mathrm{H}, \mathrm{Ar}-H), 7.6-7.5$ (br.s, $2 \mathrm{H}, \mathrm{NH}_{2}$, exchangeable with $\mathrm{D}_{2} \mathrm{O}$ ), 7.10 (d, $J=9 \mathrm{~Hz}, 2 \mathrm{H}, \mathrm{Ar}-$ H), $3.84\left(\mathrm{~s}, 3 \mathrm{H}, \mathrm{OCH}_{3}\right)$. MS (EI, m/z): $389\left(\mathrm{M}^{+}\right)$. Anal. Calcd. for $\mathrm{C}_{19} \mathrm{H}_{15} \mathrm{~N}_{7} \mathrm{O}_{3}: \mathrm{C}, 58.61 ; \mathrm{H}, 3.88 ; \mathrm{N}, 25.18$. Found: $\mathrm{C}, 58.52 ; \mathrm{H}, 3.75$; $\mathrm{N}, 25.09 \%$.

\subsubsection{7-amino-5-(4-methoxyphenyl)-3-(phenylamino)- [1,2,4]triazolo[4,3-a]pyrimidine-6-carbonitrile (11)}

A mixture of $2(1.0 \mathrm{~g}, 3.9 \mathrm{mmol})$ and phenyl isothiocyanate $(0.53 \mathrm{~mL}, 3.9 \mathrm{mmol})$ in pyridine $(25 \mathrm{~mL})$ was heated under reflux for $6 \mathrm{~h}$. After cooling the reaction mixture was poured on ice cold acetic acid. The buff solid that separated out was filtered off, washed several times with cold water and recrystallized from benzene to give $\mathbf{1 1}$ (Scheme 5). Yield 62\%. M.p.: 152-315 ${ }^{\circ} \mathrm{C}$. FT-IR $\left.\left(\mathrm{KBr}, \mathrm{cm}^{-1}\right): 3204 \mathrm{v}^{\mathrm{NHH}}, \mathrm{NH}\right), 2204$ $\mathrm{v}(\mathrm{C} \equiv \mathrm{N}) .{ }^{1} \mathrm{H}$ NMR $\left(300 \mathrm{MHz}, \mathrm{DMSO}-d_{6}\right): 9.75$ (s, $1 \mathrm{H}, \mathrm{N} H$, exchangeable with $\left.\mathrm{D}_{2} \mathrm{O}\right), 7.49-7.30(\mathrm{~m}, 5 \mathrm{H}, \mathrm{Ar}-\mathrm{H}), 6.99-6.96(\mathrm{~d}$, $J=8.4 \mathrm{~Hz}, 2 \mathrm{H}, \mathrm{Ar}-H$ ) , 6.56-6.55 (d, J=8.7 Hz, 2H, Ar- $H$ ), 4.9 (br.s, $2 \mathrm{H}, \mathrm{NH}_{2}$, exchangeable with $\left.\mathrm{D}_{2} \mathrm{O}\right), 3.34\left(\mathrm{~s}, 3 \mathrm{H}, \mathrm{OCH}_{3}\right.$ ). MS (EI, m/z): 228 (M-ph, -2CN). Anal. Calcd. for $\mathrm{C}_{19} \mathrm{H}_{15} \mathrm{~N}_{7} \mathrm{O}$ : C, 63.86; $\mathrm{H}$, 4.23; N, 27.44. Found: C, 63.87; H, 4.20; N, 27.45\%.

\subsubsection{2. $N$ '-(4-amino-5-cyano-6-(4-methoxyphenyl)pyrimidin-} 2-yl)acetohydrazide (12)

A mixture of $2(1.0 \mathrm{~g}, 3.9 \mathrm{mmol})$ and diethyl oxalate $(0.53$ $\mathrm{mL}, 3.9 \mathrm{mmol})$ in $n$-butanol $(20 \mathrm{~mL})$ in the presence of acetic acid ( $5 \mathrm{~mL}$ ), was heated under reflux for $10 \mathrm{~h}$. After cooling, a colourless solid was separated out, filtered off, dryed and recrystallized from ethanol/dioxane mixture to give $\mathbf{1 2}$ as colourless crystals (Scheme 5). Yield 83\%. M.p.: $268-270{ }^{\circ} \mathrm{C}$. FTIR $\left(\mathrm{KBr}, \mathrm{cm}^{-1}\right): 3448,3361,3299 \mathrm{v}\left(\mathrm{NH}_{2}, \mathrm{NH}\right), 2204 \mathrm{v}(\mathrm{C} \equiv \mathrm{N})$, $1668 \mathrm{v}(\mathrm{C}=0)$ (amide), $1641 \mathrm{v}(\mathrm{C}=\mathrm{N})$. MS (EI, m/z): $298\left(\mathrm{M}^{+}\right)$. Anal. Calcd. for $\mathrm{C}_{14} \mathrm{H}_{14} \mathrm{~N}_{6} \mathrm{O}_{2}$ : C, 56.37; $\mathrm{H}, 4.73 ; \mathrm{N}, 28.17$. Found: C, 56.27; H, 4.69; N, 28.19\%.

2.2.13. (Z)-5-(4-nitrobenzylidene)-6-amino-2-thioxo-2,3dihydropyrimidin-4(5H)-one (14) and 7-amino-4-hydroxy-2mercapto-5-(4-nitrophenyl)-5,8-dihydropyrido[2,3-d] pyramidine-6-carbonitrile (15)

A mixture of 13 (2.17 g, $0.01 \mathrm{~mol})$ with 6-amino-2-thioxo2,3-dihydropyrimidin- $4(1 \mathrm{H})$-one (1.43 g, $0.01 \mathrm{~mol})$ in absolute ethanol $(50 \mathrm{~mL})$ in the presence of piperidine $(1.0 \mathrm{~mL})$ was heated with stirring for $2 \mathrm{~h}$. The solid separated while hot was collected by filtration and recrystallized from dioxane to give $\mathbf{1 4}$ as yellow crystals, yield (13\%). Acidification of the alkaline filtrate after evaporation of the solvent with cold dilute acetic acid left a yellow solid which filtered off, washed several times with cold water, dried and recrystallized from DMF to give $\mathbf{1 5}$ as buff crystals (Schemes 6,7).

(Z)-5-(4-nitrobenzylidene)-6-amino-2-thioxo-2,3-dihydro pyrimidin-4(5H)-one (14): Yellow crystals. Yield 13\%. M.p.: 236-238 ${ }^{\circ} \mathrm{C}$. FT-IR $\left(\mathrm{KBr}, \mathrm{cm}^{-1}\right): 3443,3410,3155 \mathrm{v}\left(\mathrm{NH}_{2}, \mathrm{NH}\right)$, $1672 v(\mathrm{C}=0), 1632 \cup(\mathrm{C}=\mathrm{N}), 1346 \mathrm{v}(\mathrm{C}=\mathrm{S}) . \mathrm{MS}(\mathrm{EI}, \mathrm{m} / \mathrm{z}): 276$ $\left(\mathrm{M}^{+}\right)$. Anal. Calcd. for $\mathrm{C}_{11} \mathrm{H}_{8} \mathrm{~N}_{4} \mathrm{O}_{3} \mathrm{~S}: \mathrm{C}, 47.82 ; \mathrm{H}, 2.92 ; \mathrm{N}, 20.28$; , 11.61. Found: C, 47.73; H, 2.89; N, 20.29; S, 11.53\%.

7-amino-4-hydroxy-2-mercapto-5-(4-nitrophenyl)-5,8dihydropyrido[2,3-d] pyramidine-6-carbonitrile (15): Buff crystals. Yield $56.6 \%$. M.p.: over $300{ }^{\circ} \mathrm{C}$. FT-IR $\left(\mathrm{KBr}, \mathrm{cm}^{-1}\right)$ : 3431, 3325 v( $\left.\mathrm{NH}_{2}\right), 2225 \mathrm{v}(\mathrm{C} \equiv \mathrm{N}), 1639 \mathrm{v}(\mathrm{C}=\mathrm{N}) . \mathrm{MS}(\mathrm{EI}, \mathrm{m} / \mathrm{z})$ $342\left(\mathrm{M}^{+}\right)$. Anal. Calcd. for $\mathrm{C}_{14} \mathrm{H}_{10} \mathrm{~N}_{6} \mathrm{O}_{3} \mathrm{~S}: \mathrm{C}, 49.12 ; \mathrm{H}, 2.94 ; \mathrm{N}$, 24.55; S, 9.37. Found: C, 48.89; H, 2.87; N, 24.36; S, 9.26\%. 


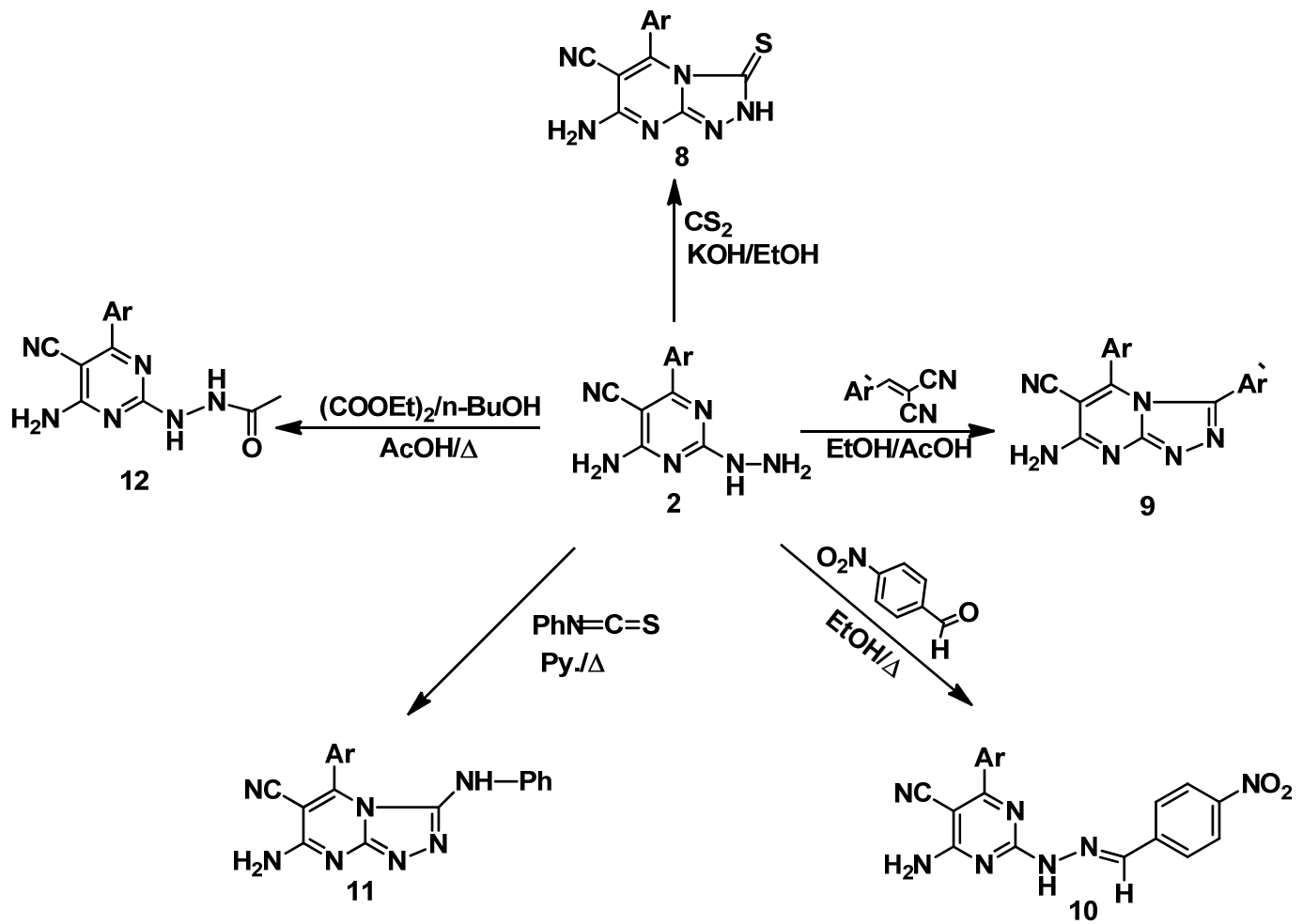

\section{$\mathrm{Ar}=\mathrm{C}_{6} \mathrm{H}_{4}-\mathrm{OMe}-4$ \\ $\mathrm{Ai}=\mathrm{C}_{6} \mathrm{H}_{3}(\mathrm{OMe})_{2}, 3: 4$}

Scheme 5

\subsubsection{4. (E)-2-(5-(4-nitrobenzylidene)-4-oxo-4,5-dihydro thiazol-2-yl)acetonitrile (17)}

A mixture of 13 (2.17 g, $0.01 \mathrm{~mol})$ with 2-(4-oxo-4,5dihydrothiazol-2-yl)acetonitrile $(1.4 \mathrm{~g}, 0.01 \mathrm{~mol})$ in absolute ethanol $(50 \mathrm{~mL})$ in the presence of piperidine $(1.0 \mathrm{~mL})$ was heated with stirring under reflux for $8 \mathrm{~h}$. After cooling the reaction mixture was poured on ice and acidified with dilute acetic acid. The separated solid was filtered off, washed several times with cold water and recrystallized from ethanol to give 17 as red crystals (Scheme 7). Yield 62.8\%. M.p.: 194-196 ${ }^{\circ} \mathrm{C}$. FT-IR (KBr, cm-1): $2208 \mathrm{v}(\mathrm{C} \equiv \mathrm{N}), 1675 \mathrm{v}(\mathrm{C}=0)$. MS (EI, m/z): $273\left(\mathrm{M}^{+}\right)$. Anal. Calcd. for $\mathrm{C}_{12} \mathrm{H}_{7} \mathrm{~N}_{3} \mathrm{O}_{3} \mathrm{~S}$ : C, 52.74; H, 2.58; N, 15.38; S, 11.73. Found: C, 52.71; H, 2.48; N, 15.41; S, 11.73\%.

\subsubsection{1,2-diamino-5-cyano-4-(4-nitrophenyl)-6-oxo-1,6- dihydropyridine-3-carboxamide (18) and (3E,5Z)-3-amino- 6-cyano-5-(4-nitrophenyl)-7-oxo-2,7-dihydro-1H-1,2-} diazepine-4-carboxamide (19)

A mixture of $13(2.17 \mathrm{~g}, 0.01 \mathrm{~mol})$ with 2cyanoacetohydrazide $(0.99 \mathrm{~g}, 0.01 \mathrm{~mol})$ in absolute ethanol (50 $\mathrm{mL})$ in the presence of piperidine $(1.0 \mathrm{~mL})$ was heated with stirring under reflux for $3 \mathrm{~h}$. The yellow solid deposited while hot was collected by filtration and recrystallized from ethanol to give 18. Acidification of the alkaline filtrate with ice cold dilute acetic acid left a yellow solid product which filtered off, washed several times with cold water, dried and recrystallized from toluene to give $\mathbf{1 9}$ (Scheme 7). 1,2-diamino-5-cyano-4-(4-nitrophenyl)-6-oxo-1,6-dihydro pyridine-3-carboxamide (18): Yield 46.5\%. M.p.: 201-203 ${ }^{\circ} \mathrm{C}$. FT-IR (KBr, cm$\left.{ }^{-1}\right): 3494,3403,3358,3289,3186 \mathrm{v}\left(\mathrm{NH}_{2}\right), 2207$ $\mathrm{v}(\mathrm{C} \equiv \mathrm{N}), 1698,1656 \mathrm{v}(\mathrm{C}=0)$. MS (EI, m/z): $314\left(\mathrm{M}^{+}\right)$. Anal. Calcd. for $\mathrm{C}_{13} \mathrm{H}_{10} \mathrm{~N}_{6} \mathrm{O}_{4}$ : C, 49.69; H, 3.21; N, 26.74. Found: C, 49.62; H, 3.18; N, 26.72\%.

(3E,5Z)-3-amino-6-cyano-5-(4-nitrophenyl)-7-oxo-2,7dihydro-1H-1,2-diazepine-4-carboxamide (19): Yield 15.7\%. M.p.: $229-230{ }^{\circ} \mathrm{C}$. FT-IR $\left(\mathrm{KBr}, \mathrm{cm}^{-1}\right)$ : $3329,3197 \mathrm{v}\left(\mathrm{NH}_{2}, \mathrm{NH}\right)$ $2210 v(\mathrm{C} \equiv \mathrm{N}), 1674 \mathrm{v}(\mathrm{C}=0)$ ). ${ }^{1} \mathrm{H}$ NMR (300 MHz, DMSO- $\left.d_{6}\right): 8.26$ (d, $J=8.4 \mathrm{~Hz}, 2 \mathrm{H}, \mathrm{Ar}-H$ ) , 7.55 (d, J=8.7 Hz, 2H, Ar- $H$ ), 7.0 (br.s, $1 \mathrm{H}$ $\mathrm{NH}$, exchangeable with $\mathrm{D}_{2} \mathrm{O}$ ), 5.58 (br.s, $2 \mathrm{H}, \mathrm{NH}_{2}$, exchangeable with $\left.\mathrm{D}_{2} \mathrm{O}\right)$. MS (EI, m/z): $314\left(\mathrm{M}^{+}\right)$. Anal. calcd. for $\mathrm{C}_{13} \mathrm{H}_{10} \mathrm{~N}_{6} \mathrm{O}_{4}$ : C, 49.69; H, 3.21; N, 26.74. Found: C, 49.67; H, 3.16; N, 26.77\%.

\subsubsection{6-cyano-7-(4-nitrophenyl)-5-oxo-2-thioxo-1,2,3,5- tetrahydro-[1,2,4]triazolo[1,5-a] pyridine-8-carboxamide (20)}

A mixture of 18 (1.0 g, $3.2 \mathrm{mmol})$ and carbon disulphide (5 $\mathrm{mL}$ ) in ethanolic $\mathrm{KOH} 10 \%(10 \mathrm{~mL})$ was heated under reflux on water bath for $16 \mathrm{~h}$. After cooling the reaction mixture was poured on ice and acidified with dilute acetic acid. The precipitated solid was filtered off, washed several times with cold water and recrystallized from methanol to give $\mathbf{2 0}$ as light brown crystals (Scheme 7). Yield 32\%. M.p.: over $300^{\circ} \mathrm{C}$. FT-IR $\left(\mathrm{KBr}, \mathrm{cm}^{-1}\right): 3421 \mathrm{v}\left(\mathrm{NH}_{2}\right), 2213 \mathrm{v}(\mathrm{C} \equiv \mathrm{N}), 1690 \mathrm{v}(\mathrm{C}=0), 1621$ $v(\mathrm{C}=\mathrm{N}), 1342 \mathrm{v}(\mathrm{C}=\mathrm{S})$. MS (EI, m/z): $322\left(\mathrm{M}-\mathrm{H}_{2} \mathrm{~S}\right)$. Anal. Calcd. for $\mathrm{C}_{14} \mathrm{H}_{8} \mathrm{~N}_{6} \mathrm{O}_{4} \mathrm{~S}$ : C, 47.19; $\mathrm{H}, 2.26$; N, 23.59; S, 9.00. Found: C, 47.15; H, 2.24; N, 23.54; S, 8.98\%. 


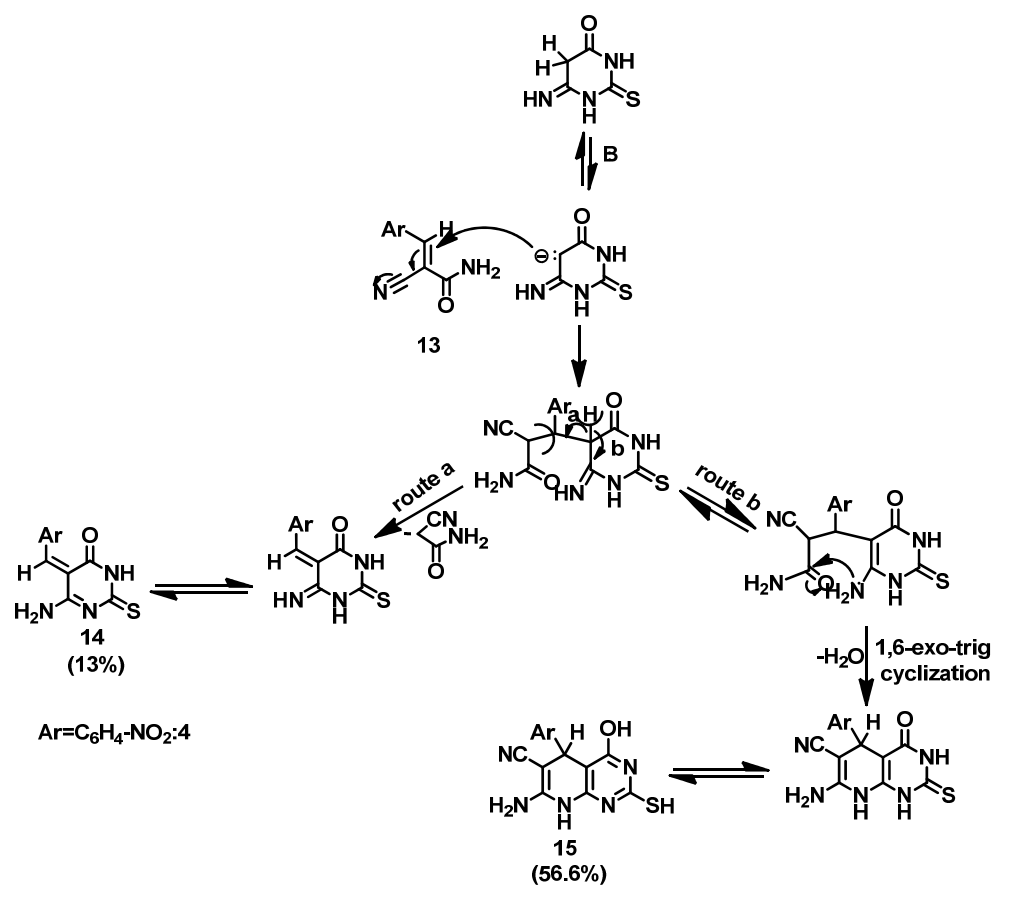

Scheme 6

\subsection{Antiviral activity}

\subsubsection{Methodology: MTT assay (Cytotoxicity assay)}

Samples were diluted with Dulbecco's Modified Eagle's Medium (DMEM) to desired concentrations. Stock solutions of the test compounds were prepared in $10 \%$ DMSO in $\mathrm{ddH}_{2} \mathrm{O}$. The cytotoxic activity of the extracts was tested in Madin Darby Canine kidney (MDCK) cells by using the 3-(4,5dimethylthiazol-2-yl)-2,5-diphenyltetrazolium bromide (MTT) method [15] with minor modification. Briefly, the cells were seeded in 96 well-plates $\left(100 \mu \mathrm{L} /\right.$ well at a density of $3 \times 10^{5}$ cells $/ \mathrm{mL}$ ) and incubated for $24 \mathrm{hrs}$ at $37{ }^{\circ} \mathrm{C}$ in $5 \% \mathrm{CO}_{2}$. After 24 hrs, cells were treated with various concentrations of the tested compounds in triplicates. After further $24 \mathrm{hrs}$, the supernatant was discarded and cell monolayers were washed with sterile phosphate buffer saline(PBS) 3 times and MTT solution $(20 \mu \mathrm{L}$ of $5 \mathrm{mg} / \mathrm{mL}$ stock solution) was added to each well and incubated at $37{ }^{\circ} \mathrm{C}$ for $4 \mathrm{hrs}$ followed by medium aspiration. In each well, the formed formazan crystals were dissolved with $200 \mu \mathrm{L}$ of acidified isopropanol $(0.04 \mathrm{M} \mathrm{HCl}$ in absolute isopropanol). Absorbance of formazan solutions were measured at $\lambda_{\max } 540 \mathrm{~nm}$ with $620 \mathrm{~nm}$ as a reference wavelength using a multi-well plate reader. The percentage of cytotoxicity compared to the untreated cells was determined with the equation (1).

$\%$ Cytotoxicity $=$ Abs. of cells without treatment-Abs. of cells with

Abs. of cells without treatment

The plot of \% cytotoxicity versus sample concentration was used to calculate the concentration, which exhibited $50 \%$ cytotoxicity (LD50).

\subsubsection{Antiviral assay}

The antiviral activity of the compounds was determined using cytopathogenicity (CPE) assay against avian influenza virus (H5N1). Stock solutions of the test compounds were prepared in DMSO at a concentration of $10 \mathrm{mg} / \mathrm{mL}$. Cells grown to confluency in 96-well plates, were infected with $100 \mu \mathrm{L}$ of stock virus. After an adsorption period of 2 hrs at $37{ }^{\circ} \mathrm{C}$, virus was removed and serial dilutions of the compounds were added. Maintenance DMEM with 2\% FBS was added (100 $\mu \mathrm{L} /$ well).The cultures were further incubated at $37^{\circ} \mathrm{C}$ for 3 days, until complete CPE was observed in the infected and untreated virus control. The determination of the anti-influenza virus activity of the compounds was based on virus-induced cytopathogenicity of H5N1-infected MDCK cells, measured at day 4 post virus infection by the MTT colorimetric method [16] An absorbance of formazan was detected by a multi-well plate reader at $540 \mathrm{~nm}$ with $620 \mathrm{~nm}$ reference wavelength.

\section{Results and discussion}

\subsection{Synthesis}

The utility of activated nitriles in synthesis of a wide variety of heterocyclic systems [17-26] encouraged us to synthesize pyrimidine derivatives from relatively simple starting materials. The title compound $\mathbf{1}$ was prepared by reaction of 2-(4-methoxybenzylidene)malononitrile with s-benzylthiuronium chloride in refluxing ethanolic sodium hydroxide according the simple mechanism in (Scheme 1).

Hydrazinolysis of $\mathbf{1}$ afforded the sulfur free compound which identified as 4-amino-2-hydrazinyl-6-(4-methoxy phenyl)pyrimidine-5-carbonitrile (2) [6] (Scheme 2).

Recently, it has been reported [27] that the hydrazino pyrimidines can be considered as key starting materials for the synthesis of diverse nitrogen bridgehead compounds. This prompted us to reinvestigate the proclivity of compound $\mathbf{2}$ with electrophilic reagents such as, pentane-2,4-dione, acetic anhydride, furoyl chloride, phthalic anhydride, ethyl chloroformate, carbon disulphide, 2-(3,4-dimethoxybenzylidene) malononitrile, $p$-nitrobenzaldehyde, phenyl isothiocyanate and diethyl oxalate with the aim of preparing new pyrimidine derivatives which might have chemotherapeutic and biological evaluation. 


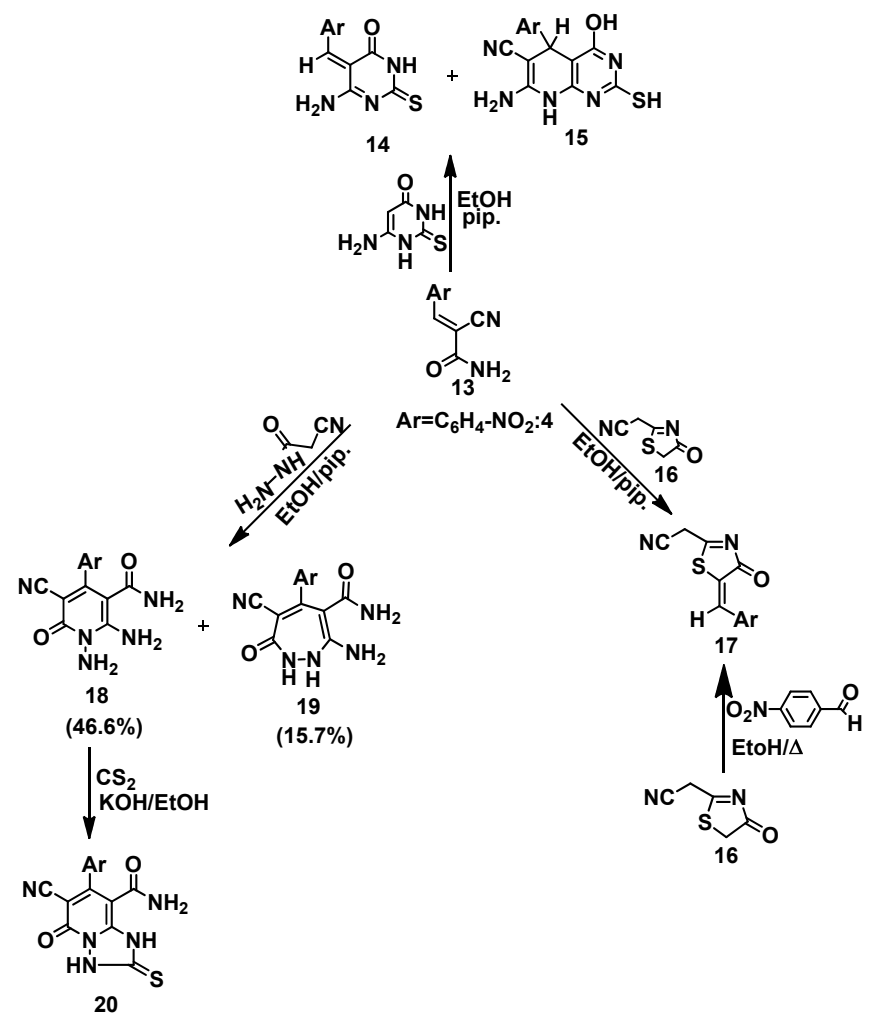

Scheme 7

Thus, treatment of the 2-hydrazino derivative 2 with pentane-2,4-dione in refluxing ethanol afforded 4-amino-2(3,5-dimethyl-1H-pyrazol-1-yl)-6-(4-methoxyphenyl)pyrimidine-5-carbonitrile (3) [6].

Acetylation of compound 2 using freshly distilled acetic anhydride yielded the acetylated product (4). The mass spectrum of this product indicates the incorporation of three acetyl groups which also confirmed from its ${ }^{1} \mathrm{H}$ NMR spectrum. On the other hand, treatment of $\mathbf{2}$ with furoyl chloride afforded the monoacylated product (5). However, the reaction of $\mathbf{2}$ with phthalic anhydride in refluxing acetic acid gave the phthalimide derivative (6). Furthermore, compound 2 when treated with ethyl chloroformate yielded ethyl $N$-pyrimidin-2-yl carbazate derivative (7) (Scheme 2).

The structures 4-7 were substantiated from the correct analytical and spectroscopic data (c.f. Exp.). The formation of compounds 4-7 could be explained on the basis of nucleophilic substitution at trigonal carbon (tetrahedral mechanism).

It has been reported that heterocyclic o-aminocarbonitriles including furans, pyrimidines and quinazolines [28] reacted with carbon disulphide under different conditions to afford biologically interest fused thiazines and pyrimidinedithione. However, compound $\mathbf{2}$ was treated with carbon disulphide in ethanolic potassium hydroxide to yield 7-amino-5-(4methoxyphenyl)-3-thioxo-2,3-dihydro-[1,2,4]-triazolo[4,3- $a$ ] pyrimidine-6-carbonitrile (8) (Scheme 5). This reaction could be visualized as shown in (Scheme 3).

7-Amino-3-(3,4-dimethoxyphenyl)-5-(4-methoxyphenyl)$[1,2,4]$ triazolo $[4,3-a]$ pyrimidine-6-carbonitrile (9) was obtained in fairly good yield upon treatment of compound 2 with 2-(3,4-dimethoxybenzylidene)malononitrile in boiling ethanol in the presence of few drops of acetic acid (Scheme 5). The structure of $\mathbf{9}$ was deduced from the correct analytical and spectroscopic data (c.f. Exp.). Formation of compound 9 could be postulated as shown in (Scheme 4).

Refluxing the hydrazino derivative $\mathbf{2}$ with $p$-nitro benzaldehyde in ethanol for 10 min afforded a crude yellow solid with molecular formula $\mathrm{C}_{19} \mathrm{H}_{15} \mathrm{~N}_{7} \mathrm{O}_{3}\left[\mathrm{M}+{ }^{+}=389(6.5 \%)\right]$ which detected as $(E)$-2-(2-(4-nitrobenzylidene)hydrazinyl)-4amino-6-(4-methoxyphenyl)pyrimidine-5-carbonitrile (Scheme 5).

In the context, it was claimed that the reaction of the hydrazino derivative with phenyl isothiocyanate in refluxing pyridine resulted in the formation of 1,2,4-triazolopyrimidinthione or thiourea derivatives [27]. Herein, when compound 2 was refluxed with the same reagent in boiling pyridine afforded the sulfur free product with molecular formula $\mathrm{C}_{19} \mathrm{H}_{15} \mathrm{~N}_{7} \mathrm{O}\left[\mathrm{M} \cdot{ }^{+}=357\right]$ which detected as 7-amino-5-(4methoxyphenyl)-3-(phenylamino)-[1,2,4]triazolo[4,3- $a$ ]pyrimidine-6-carbonitrile (11) (Scheme 5).

Treatment of $\mathbf{2}$ with diethyl oxalate in refluxing $n$-butanol in the presence of acetic acid afforded the mono acetylated product (12) which indicates that no combination occurred between compound 2 and the oxalate in the presence of acetic acid. This confirmed by refluxing 2 with acetic acid in $n$-butanol which yielded the same product $\mathbf{1 2}$ (Scheme 5).

As a continuation [29-31] of our study on the reactivity of activated nitriles, the (E)-2-cyano-3-(4-nitrophenyl)acrylamide (13) was prepared and allowed to react with carbon and nitrogen nucleophiles. Thus, the reaction of $\mathbf{1 3}$ with 6-amino-2thioxo-2,3-dihydropyrimidin-4(1H)-one in boiling ethanol in the presence of piperidine yielded a yellow solid product separated on hot and identified as the pyrimidine derivative $\mathbf{1 4}$ $(13 \%)$. Acidification of the alkaline filtrate left a solid product which detected as the pyrido[2,3- $d]$ pyrimidine derivative $\mathbf{1 5}$ (56.6\%) (Scheme 7). 


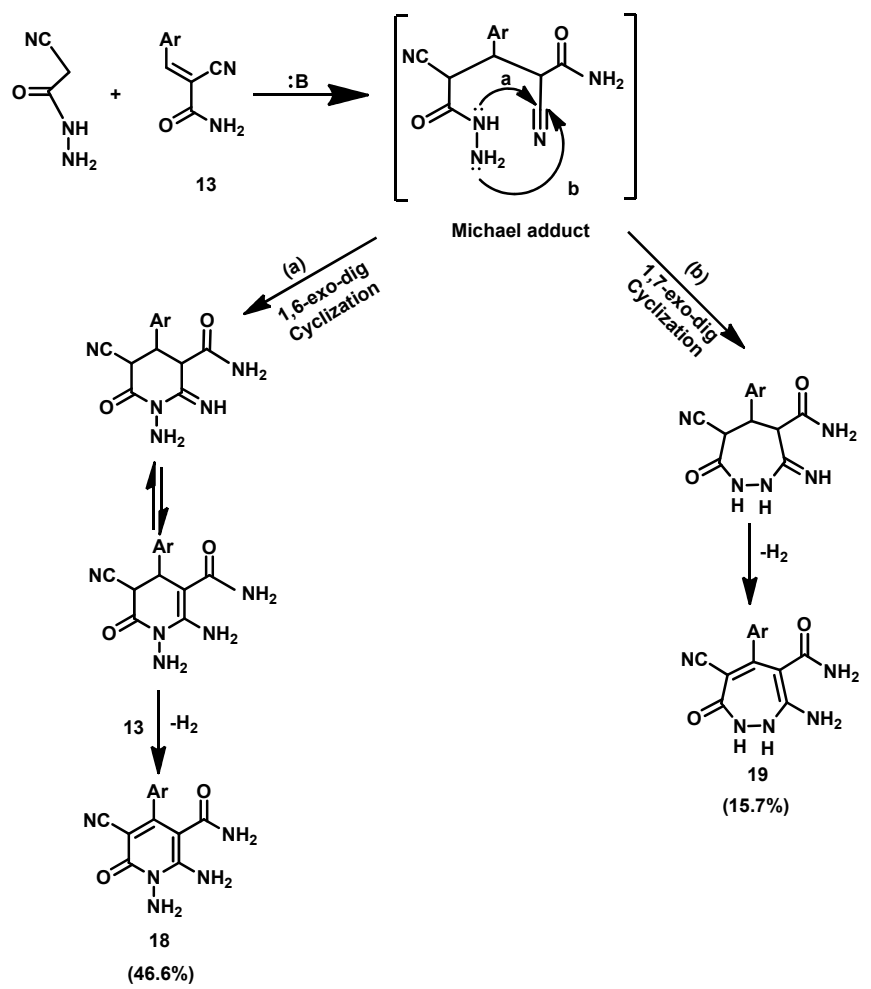

Scheme 8

The reaction was assumed to proceed via Michael addition of the C-5 of pyrimidine nucleus to the $\alpha, \beta$-unsaturated nitrile 13 and subsequent 1,6-exo-trig cyclization through nucleophilic addition of the amino group to the carboxamido carbonyl group (Scheme 6).

Furthermore, treatment of 13 with 2-(4-oxo-4,5dihydrothiazol-2-yl) acetonitrile (16) in boiling ethanol in the presence of catalytic amount of piperidine afforded $(E)$-2-(5-(4nitrobenzylidene)-4-oxo-4,5-dihydrothiazol-2-yl)acetonitrile

(17) as the sole product (62.8\%) (Scheme 7). The structure 17 was chemically supported by identity with an authentic sample resulted from the condensation of $\mathbf{1 6}$ with $p$-nitrobenzaldehyde (Scheme 7).

$\mathrm{N}$-Amino-2-pyridones have proved to be useful synthetic intermediates [32-35]. However, there are few synthetic procedures for the preparation of N-amino-2-pyridones. These compounds are usually obtained [36-39] in low yields by reaction of hydrazine with 2-pyrones, which are in turn prepared in low yields from open chain compounds [35-44]. We report in this article one step synthesis of $\mathrm{N}$-amino-2pyridone (18) from compound 13 with 2-cyanoacetohydrazide. The reaction easily performed in ethanol at room temperature in the presence of piperidine by stirring for two hours. The separated solid was identified using analytical and spectral data as 1,2-diamino-5-cyano-4-(4-nitrophenyl)-6-oxo-1,6dihydropyridine-3-carboxamide (18). Acidification of the mother liquor left another yellow solid which have the same molecular formula of compound 18. This product was expected to have the diazepinone structure 19 (Scheme 7).

The reaction may be assumed to proceed via Michael addition of 2-cyanoacetohydrazide to $\mathbf{1 3}$ and the resulting adduct undergoes in situ cyclization by nucleophilic attack at the cyano group to give the six membered ring which on aromatization gives rise to the $\mathrm{N}$-amino-2-pyridone (18) (route a). A cyclization to seven-membered diazepine ring must be favored by the higher nucleophilic character of the amino group with respect to the CONH group, but the poor yield of $\mathbf{1 9}$, probably due to the lack of aromatic character of the diazepinone ring 19 (Scheme 8).

Beside the analytical and spectral data the structure 18 was got a further chemical support by the reaction with carbon disulphide. However, when compound $\mathbf{1 8}$ was treated with carbon disulphide in ethanolic potassium hydroxide at refluxing temperature yielded 1,2,4-triazolo[1,5- $a$ ]pyridine derivative 20 (Scheme7).

\subsection{Biological activity test results}

The results were expressed as the $50 \%$ effective concentration $\left(\mathrm{EC}_{50}\right)$. The $50 \%$ effective antiviral concentration $\left(\mathrm{EC}_{50}\right)$ was defined as the compound concentration required for protecting $50 \%$ of the virus-infected cells against viral cytopathogenicity. The therapeutic index was calculated by dividing $\mathrm{LD}_{50}$ on $\mathrm{EC}_{50}$ (Figure 1).

Therapeutic index was calculated to all examined compounds and compared with Zanamivir as control antiinfluenza drug as shown in Table 1.

Table 1. Therapeutic index of the tested compounds comparing with zanamivir.

\begin{tabular}{ll}
\hline Compound & Therapeutic index \\
\hline 1 & 0.896257387 \\
2 & 0.449688858 \\
3 & 0.444114591 \\
4 & 0.437320824 \\
5 & 0.358697928 \\
6 & 0.521603236 \\
7 & 0.677685950 \\
8 & 0.465886618 \\
9 & 0.533377287 \\
10 & 0.749826429 \\
11 & 0.598077678 \\
12 & 0.440400844 \\
Zanamivir & 15.4 \\
\hline
\end{tabular}




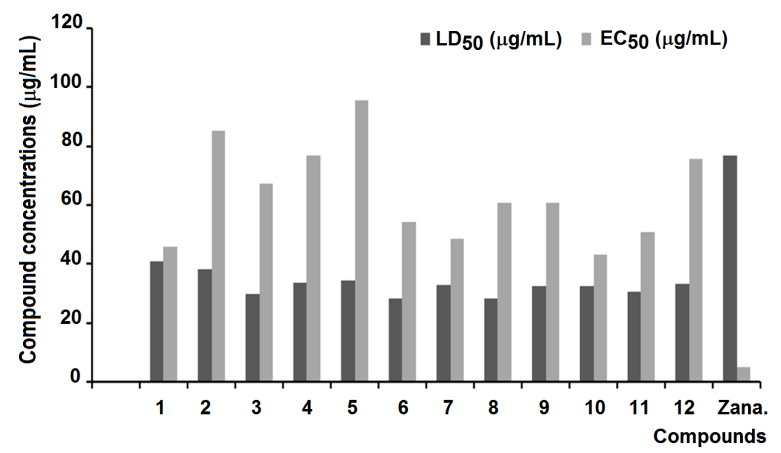

Figure 1. The $50 \%$ effective concentration $\left(\mathrm{EC}_{50}\right)$ and the concentration, which exhibited $50 \%$ cytotoxicity $\left(\mathrm{LD}_{50}\right)$ of the tested compounds. The results were compared with the anti-influenza drug, zanamivir. Compounds $\mathbf{1}$ and $\mathbf{1 0}$ showed the highest therapeutic index than the other compounds.

\section{Conclusions}

The potentially synthetic value of the newly reported compounds, as excellent starting materials, stimulated our interest to utilize them for the synthesis of the title compounds, in anticipation that new compounds would exhibit pharmacological activity. All the synthesized compounds were examined and compared with Zanamivir as control antiinfluenza drug and only compounds $\mathbf{1}$ and $\mathbf{1 0}$ showed the highest therapeutic index than the others.

\section{Acknowledgements}

The biological activity was supported by Mohamed A. Ali and Ahmed M. Mostafa, Division of Environmental Researches, National Research Centre, Dokki, Giza, Egypt.

\section{References}

[1]. Cordeu, L.; Cubedo, E.; Bandres, E.; Rebollo, A.; Saenz, X.; Chozes, H. M.; Dominquez, V.; Echeverria, M.; Mendivil, B.; Sanmartin, C.; Palop, J. A.; Font, M.; Garcia-Foncillas. J. Bioorg. Med. Chem. 2007, 15, 1659-1669.

[2]. Wang, Y. P.; Chen, F. E.; Clercq, E. D.; Balzarini, J.; Pannecouque, C. Eur. J. Med. Chem. 2009, 44, 1016-1023.

[3]. El-Gazzar, A. B. A.; El-Enany, M. M.; Mahmoud, M. N. Bioorg. Med. Chem. 2008, 16, 3261-3273.

[4]. Bernier, J. L.; Henichart, J. P.; Warin, V.; Baert, F. J. Pharm. Sci. 1980, 69, 1343-1345.

[5]. Powers, D. L.; Sowell Sr, J. W.; Freeman, J. J.; Kosh, J. W. J. Pharm. Sci. 1980, 69(4), 473-475

[6]. El-Agrody, A.; Ali, F.; Eid, F.; El-Nassag, M.; El-Sherbeny, G.; Bedair, A. J. Phosphorus sulfur 2006, 181(4), 839-864.

[7]. He, Y. Z.; Li, Y. X.; Zhu, X. L.; Xi, Z.; Niu, C.; Wan, J.; Zhang, L.; Yang, G. F. J. Chem. Inf. Model. 2007, 47(6), 2335-2344.

[8]. Li, Y. X.; Luo, Y. P.; Xi, Z.; Niu, C.; He, Y. Z.; Yang, G. F. J. Agric. Food Chem. 2006, 54(24), 9135-9139.

[9]. El-Gazzar, A. B. A.; Youssef, M. M.; Youssef, A. M. S.; Abu-Hashem, A. A.; Badria, F. A. Eur. J. Med. Chem. 2009, 44, 609-624.

[10]. Kumar, R.; Nair, R. R.; Dhiman, S. S.; Sharma, J.; Prakash, O. Eur. J. Med. Chem. 2009, 44(5), 2260-2264.

[11]. Chen, Q.; Liu, Z. M.; Chen, C. N.; Jiang, L. L.; Yang, G. F. Chem. Biodivers. 2009, 6, 1254-1265.

[12]. Hafez, H. N.; El-Gazzar, A. B. A. Bioorg. Med. Chem. Lett. 2009, 19, 4143-4147.

[13]. Chhabria, M. T.; Jani, M. H. Eur. J. Med. Chem. 2009, 44, 3837-3844.

[14]. Narayana, B. L.; Rao, A. R. R.; Rao, P. S. Eur. J. Med. Chem. 2009, 44, 1369-1376.

[15]. Mossman, T. J. Immunol. Methods. 1983, 65, 55-63.

[16]. Pauwels, R.; Balzarini, J.; Baba, M.; Snoeck, R.; Schols, D.; Herdewijn, P.; Desmyter, J.; De Clercq, E. J. Virol. Methods 1988, 20, 309-321.

[17]. Abdel-Galil, F. M.; Sallam, M. M.; Sherif, S. M.; Elnagdi, M. H. Heterocycles. 1986, 24(12), 3341-3346.

[18]. Khodairy, A.; El-Sayed, A. M.; Salah, H.; Abdel-Ghany, H. Synth. Commun. 2007, 37, 639-647.

[19]. Mahmoud, M. R.; El-Bordainy, E. A. A.; Hassan, N. F.; Abu El-Azm, F. S. M. Phosphorus sulfur 2007, 182, 2507-2521.
[20]. Elnagdi, M. H.; Sherif, S. M.; Mohareb, R. M. Heterocycles. 1987, 26(2), 497-536.

[21]. Mahmoud, M. R.; Madkour, H. M. F.; El-Bordainy, E. A. A.; Soliman, E. A. Phosphorus sulfur 2009, 184, 156-163.

[22]. Kambe, S.; Saito, K.; Sakurai, A.; Midorikawa, H. Synthesis. 1980, 10, 839-840.

[23]. El-Sayed, A. M.; Khodairy, A. Synth. Commun. 1998, 28(18), 33313343.

[24]. Madkour, H. M. F.; Mahmoud, M. R.; Nassar, M. H.; Habashy, M. M. Sulfur. Lett. 1998, 21(6), 253-261.

[25]. Madkour, H. M. F.; Mahmoud, M. R.; Sakr, A. M.; Habashy, M. M. Sci. Pharm. 2001, 69, 33-52.

[26]. Geies, A. A. J. Chinese. Chem. Soc. 1999, 46, 69-75.

[27]. Mahmoud, M. R.; El-Bordainy, E. A. A.; Azab, M. E.; Soliman, E. A Phosphorus sulfur 2007, 182, 1275-1289.

[28]. Mahmoud, M. R.; Madkour, H. M. F.; El-Bordainy, E. A. A.; Soliman, E. A J. Chem. Res. 2007, 11, 673-676.

[29]. Freeman, F. Chem. Rev. 1980, 80(4), 329-350.

[30]. Shiba, S. A.; El-Ziaty, A. K.; El-Aasar, N. K.; Al-Saman, H. A. J. Chem. Res. 2008, 9, 500-506.

[31]. Madkour, H. M. F.; Shiba, S. A.; Sayed, H. M.; Hamed, A. A. Sulfur. Lett 2007, 24, 151-179.

[32]. Chen, Y.; Wehrmann, R.; Koehler, B. Ger Offen DE. 19, 505, 940 (C1. C07D311/16), 22 Aug, 1996: Chem. Abstr. 1996, 125, 221585w.

[33]. Bapat, J. B.; Blade, R. J.; Boulton, A. J.; Epsztajn, J.; Katritzky, A. R ; Lewis, J.; Molina-Buendia, P.; Pai-Lin Nie; Ramsden, C. A. Tetrahedron Lett. 1976, 17, 2691-2694.

[34]. Molina, P.; Soler, A.; Vilaplana, M. J.; Katritzky, A. R. An. Quim. 1978, 74(7-8), 1125-1127.

[35]. Katritzky, A. R.; Molina, P. J. Chem. Soc. Perkin Trans 1 1979, 1957 1960.

[36]. Molina, P.; Alajarin, M.; Fresneda, P. M.; Soler, A. An. Quim. 1979, 75, 124-130.

[37]. Wiley, R. H.; Slaymaker, S. C. J. Amer. Chem. Soc. 1956, 78, 2393-2403.

[38]. El-Kholy, I. E.; Rafla, F. K.; Soliman, G. J. Chem. Soc. 1961, 4490-4498.

[39]. El-Kholy, I. E.; Rafla, F. K.; Mishrikey, M. M. J. Chem. Soc. C. 1970, 11, 1578-1584.

[40]. Rees, C. W.; Yelland, M. J. Chem. Soc. Perkin Trans 1. 1972, 77-82.

[41]. Arndt, F.; Eistert, B. Ber. Dtsch. J. Chem. Soc. 1925, 58, 2318-2324.

[42]. Putter, R.; Dilthey, W. J. Prakt. Chem. 1937, 149, 183-194.

[43]. Soto, J. L.; Seoane, C.; Zammorano, P.; Javier, F. Synthesis. 1981, 7, 529530.

[44]. Sallam, M. M.; Naser, Y. A.; Elmoghayer, M. R. H. J. Herterocyclic Chem. 1984, 21, 1885-1887. 